\title{
Biochemical Markers in Saliva of Patients with Diabetes Mellitus
}

\author{
Biljana Andjelski-Radičević ${ }^{1}$ Radica Dožić ${ }^{2}$, Tatjana Todorović1, Ivan Dožić ${ }^{1}$ \\ ${ }^{1} G e n e r a l$ and Oral Biochemistry, Faculty of Dental Medicine, University of Belgrade, Belgrade, Serbia; \\ ${ }^{2}$ Faculty of Medical Sciences, University of Kragujevac, Kragujevac, Srbija
}

\begin{abstract}
SUMMARY
Diabetes mellitus is metabolic syndrome characterised by disorder in metabolism of carbon hydrates, lipids and proteins. The diagnosis of diabetes is established by measuring the blood glucose level using standardized methods. Frequent monitoring of blood glucose level could be inconvenient for patients because of possible pain during blood sample taking. In the last few years biological materials with non invasive sampling, like saliva, have been analysed. Research has confirmed that some organic and inorganic components of saliva are modified in diabetic patients (glucose, lipid and protein components, oxidative stress markers, electrolytes). Beside other markers, the analysis of glucose in saliva is an attempt to find a non-invasive and painless way for frequent monitoring of glucose concentration in diabetic patients. Collecting saliva is simple and economical, it neither requires expensive equipment nor specially trained staff. Saliva can be taken many times and in unlimited quantity. In regards to the data about the possibilities for using saliva as biological sample in monitoring diabetes mellitus, which could be alternative to blood serum or plasma, the conclusion is that saliva becomes more important in this context.
\end{abstract}

Keywords: diabetes mellitus; electrolytes; glucose; oxidative stress markers; proteins; saliva

\section{INTRODUCTION}

Diabetes mellitus (DM) is a metabolic syndrome characterized by disturbances in the metabolism of carbohydrates, lipids and proteins. It considers chronic hyperglycemia as the result of insulin secretion breakdown, or increased cellular resistance to insulin action. Etiologic classification of DM is: type 1 diabetes ( $\beta$-cell destruction, absolute insulin deficiency), type 2 diabetes (predominant insulin resistance with relative insulin deficiency to insulin secretory deficiency with insulin resistance), other specific types of diabetes, gestational diabetes. Poor glycemic control in this disease leads to poor health and the appearance of various complications such as retinopathy, nephropathy, neuropathy, cardiovascular symptoms etc. [1]. Patients with diabetes are prone to complications, such as periodontal disease (gingivitis, periodontitis), dental caries, salivary dysfunction, dry mouth, oral mucosal diseases, oral infections (candidiasis) [2-7].

The diagnosis of DM is established by determining the concentration of glucose in blood serum using standardized methods. However, monitoring blood glucose levels at frequent intervals causes discomfort for patients during the procedure of venipuncture, why many patients do not regularly monitor blood glucose concentration. In the recent years, efforts have been made to replace blood test with other biological material samples that could be collected by non-invasive procedure. One of these samples can certainly be saliva. It has many advantages over serum, such as inexpensive and non invasive collection procedure, including ease of storage and delivery [8-13].

\section{SALIVA AS DIAGNOSTIC FLUID}

Saliva is body fluid with complex composition and specific roles. The analysis of biochemical constituents in saliva is of great help in diagnostics of diseases in oral cavity [14-17] as well as monitoring general health of organism [8]. Based on numerous studies, it has been proved that there is a modification of organic and inorganic constituents of saliva in diabetic patients $[18,19]$.

\section{GLUCOSE}

In diabetic patients, as the consequence of hyperglycemia, glucose metabolic products cause microvascular changes in blood vessels and basal membranes of cells in salivary glands and oral tissues [20]. All these changes cause easier moving of glucose from blood to saliva and gingival fluid. There is available different data in the literature about the relationship between the concentration of glucose in blood and saliva. Glucose is present in saliva of healthy subjects $[21,22]$, but the mechanism of its secretion is not yet known. Proposed paracelullar and intracellular secretion pathways are still hypotheses that have not been validated yet. In patients with type 1diabetes, there has 
been proved increased $[23,24,25]$ or decreased glucose concentration in saliva [26] as compared to the control (healthy) group. In saliva of patients with type 2 diabetes, the glucose concentration is higher than in nondiabetic patients [27, 28, 29]. Lasisi \& Fasanmade [30] have shown higher concentration of glucose in saliva of diabetic patients as compared to non-diabetics, regardless of periodontal disease presence. This result has indicated that the concentration of glucose in saliva depends on its concentration in serum. However, some studies have indicated no correlation between glucose concentrations in blood and saliva in diabetic patients [28, 31, 32, 33]. Authors believe that increased presence of glucose in saliva in diabetic patients may favor proliferation of microorganisms and promote their colonization on teeth and oral mucosa. The analysis of glucose level in saliva is an attempt to find a non-invasive and painless method for frequent monitoring of blood glucose in diabetic patients.

\section{LIPID STATUS}

There is also a disorder of fat metabolism in diabetic patients, which is the consequence of disrupted glucose metabolism and changes in insulin secretion and insulin action. As the result of systemic dyslipidemia, high concentrations of lipid fractions in blood and saliva have been demonstrated in these patients. Increased cholesterol levels in saliva of patients with type 1 diabetes [26] have been demonstrated whereas in type 2 diabetes cholesterol and triglyceride concentrations have been found increased both in serum and saliva as compared to the control group [34]. Cholesterol concentration in saliva is correlated to the concentration in serum. In healthy individuals, this positive correlation can be used for the selection of individuals with high levels of serum cholesterol [35].

\section{OXIDATIVE STRESS MARKERS}

Oxidative stress plays an important role in the pathogenesis and complications of diabetes. Hyperglycemia leads to increased production of free oxygen radicals and disturbance of antioxidant defense mechanisms [36]. The most significant negative effect of free radicals is polyunsaturated fatty acids oxidation in cellular membranes known as lipid peroxidation which can damage plasma membrane. The end product of lipid peroxidation is short chained malondialdehyde (MDA) which serves as a biochemical marker of the degree of oxidative damage in cell membranes. Our research suggests increased MDA in the saliva of patients with periodontal disease as compared to the group of healthy subjects $[37,38]$. This marker is found increased in saliva of patients with type 2 diabetes [34,39], indicating that the increase of MDA may be high risk marker for complications in patients with poorly controlled diabetes. However, other studies have demonstrated lower concentration of MDA in saliva of diabetic patients than in the control group [33]. The analysis of total antioxidant capacity of saliva in diabetic patients has been the subject of several studies. Increased levels of glutathione peroxidase, glutathione reductase, superoxide dismutase and uric acid have been demonstrated in saliva of these patients $[34,40]$. Increased level of antioxidants in saliva and serum is diabetic response to the damaging effects of free radicals during oxidative stress. Based on the present results it can be concluded that free radicals and oxidative stress may play an important role in the pathogenesis of diabetes. As long as there is a balance between the production of free radicals and antioxidant activity of salivary defense system there will not be oxidative damage of tissues. In case of imbalance between the production of free radicals and/or salivary antioxidant capacity to neutralize them, oxidative stress, which can be biochemical basis for oral diseases in diabetic patients, can occur.

\section{PROTEINS}

There has been found a different data in the literature regarding the concentration of total proteins in saliva of patients with diabetes. Studies have indicated that the total proteins concentration in saliva of diabetics is lower [18, $41,42,43]$, significantly increased [19, 31, 32, 44, 45], or with no difference to the control group $[25,27,30,46]$. Our studies demonstrated lower concentrations of proteins in saliva of patients with type 1 diabetes as compared to type 2 diabetes [18], in contrast to other authors [19]. The most common blood protein, albumin, was detected in higher concentrations in saliva of diabetic as compared to saliva of healthy children, but without statistical significance [26]. Other authors have pointed reduced concentration of albumin in saliva of patients with type 2 diabetes [32]. No difference in the concentration of albumin in saliva between patients with type 1 diabetes and control group as well as between type 1 and type 2 diabetes has also been shown [47]. This data is in accordance to the results of our study [18]. Different results about proteins concentration in diabetic patients may be explained by the fact that the analysis was performed in different stages of disease, or in different types of diabetes. The total proteins concentration was most probably affected by the type and method of collecting saliva, method of stimulation, flow, measurement, diurnal variation, speed and duration of centrifugation.

In the last few years, with technological development, more specific and sensitive techniques for detection of total saliva proteins or peptides, known as salivary proteome have been used. Analysis and identification of the proteome is important not only for understanding of oral pathophysiology, but also because it may be useful as a potential biomarker for systemic disease. Researchers have confirmed about a thousand salivary proteins with different role in metabolic processes, immune regulation, cell adhesion and communication, etc. In saliva of patients with type 2 diabetes, the proteome of 487 proteins, including 65 proteins that were significant for differentiation of diseased patients from the control group have been identified $[48,49,50]$. Most of these proteins are involved in metabolic processes and immune response. 


\section{ELECTROLYTES}

Changes in serum electrolyte concentrations can affect systemic disease. However, they can influence saliva and its role in remineralisation, maintaining buffer capacity, reducing the sense of smell etc. Saliva is saturated with calcium ions that are in equilibrium with hydroxyapatite ions of tooth enamel. In addition, calcium ions from saliva play a role in binding various inorganic and organic substances to the surface of tooth enamel. These ions also play a role in enamel remineralisation $[8,51]$. The concentration of calcium in saliva varies depending on the concentration of salivary proteins, salivary flow rate and salivary gland secretion [52]. Diabetic patients have demonstrated an increase in calcium concentration in saliva compared to the control group $[19,25,53]$. Some authors believe that a high concentration of calcium in saliva is favorable indicator of oral health. However, there are conflicting results in the literature $[23,31,44,54]$. It is assumed that lower concentration of calcium ions in saliva of diabetic patients is associated with decrease in a flow rate, or with an increase of the concentration of specific proteins which make special bonds with calcium phosphate. Mata et al. [19] demonstrated lower concentrations of magnesium, zinc and potassium in saliva of diabetic patients, which is associated with the dysfunction of salivary glands secretory capacity. In our research, the concentration of potassium in saliva of diabetic patients was higher than in healthy subjects [18]. This is in agreement with other results that found changed activity of Na-K-ATP-ase, due to the changes in the basal membrane of salivary gland acini [44], or decrease in salivary secretion [30] in diabetes. The concentration of potassium can be reduced $[19,42]$ or with no change in saliva of diabetic patients [45]. The same authors reported conflicting results for the concentration of sodium.

\section{CONCLUSION}

Knowing the possibilities of using saliva as a biological sample in the diagnosis of diabetes mellitus, as an alternative to blood serum, the conclusion is that this secretion is increasingly gaining importance in this context. Collecting saliva is easy and painless for the patient, it neither requires expensive equipment nor specially trained staff. It is also possible to obtain saliva several times in unlimited quantities. The disadvantage is, however, that saliva does not reflect the real concentration of all parameters from blood. There is a problem with extremely high viscosity of saliva, due to the existing mucopolysaccharides and mucoproteins which can interfere with analytical procedure. Despite these limiting circumstances, extensive research performed by increasingly sophisticated techniques suggests that saliva will be diagnostic fluid in future.

\section{REFERENCES}

1. American Diabetes Association. Diagnosis and classification of diabetes mellitus. Diabetes Care. 2010; 33(Suppl 1):S62-9.
2. Anđelski-Radičević B, Zelić O, Mirković S, Todorović T. Stanje tkiva parodoncijuma kod pacijenata sa diabetes mellitus-om u populaciji Beograda. Vojnosanit Pregl. 2008; 65:799-802.

3. Ship JA. Diabetes and oral health. J Am Dent Assoc. 2003; 134:4-10.

4. Lamster IB, Lalla E, Borgnakke WS, Taylor GW. The relationship between oral health and diabetes mellitus. J Am Dent Assoc. 2008; 139(Suppl):19S-24S.

5. Gandara BK, Morton TH. Non-periodontal oral manifestations of diabetes: a framework for medical care providers. Diabetes Spectrum. 2011; 24:199-205.

6. Bastos AS, Leite AR, Spin-Neto R, Nassar PO, Massucato EM, Orrico SR. Diabetes mellitus and oral mucosa alterations: prevalence and risk factors. Diabetes Res Clin Pract. 2011; 92:100-5.

7. Ronningen KS, Enersen M. Diabetes and oral health. Norks Epidemiologi. 2012; 22:47-53.

8. Todorović T, Dožić I. Pljuvačka i oralno zdravlje. Beograd: Čigoja štampa; 2009.

9. Bhargavi Krishna A, Ashalatha G, Venkat Baghirath P, Rajani Kanth AV, Malathi N. Saliva as a diagnostic bio fluid. J Orofac Sci. 2010; 2:66-77.

10. Kaufman E, Lamster IB. The diagnostic applications of saliva: a review. Crit Rev Oral Biol Med. 2002; 13:197-212.

11. Pfaffe T, Cooper-White J, Beyerlein P, Kostner K, Punyadeera C. Diagnostic potential of saliva: current state and future applications. Clin Chem. 2011; 57:675-87.

12. Wong DT. Salivary diagnostics powered nanotechologies, proteomics and genomics. JADA. 2006; 137:313-21.

13. Sandhu AV, Bhandari R, Gupta S, Puri A. Salivary diagnostics: an insight. Indian Journal of Dental Sciences. 2011; 5:19-23.

14. Todorovic T, Dozic I, Barrero MV, Ljuskovic B, Pejovic J, Marjanovic $M$, et al. Salivary enzymes and periodontal disease. Med Oral Patol Oral Cir Bucal. 2006; 11:E115-9.

15. Dožić I, Todorović T. Antimikrobni proteini pljuvačke. Stomatološki glasnik Srbije. 2005; 52:208-16.

16. Todorović T, Dožić I, Pavlica D, Marković D, Brajović G, Stefanović $\mathrm{G}$, et al. Pljuvačka kao dijagnostička tečnost u stomatologiji. Srp Arh Celok Lek. 2005; 133:372-8.

17. Pavlica D, Todorović T. Saliva - dijagnostička tečnost? Stomatološki glasnik Srbije. 2001; 48:137-41.

18. Anđelski-Radičević B, Mirković S, Todorović T, Zelić O. Promene biohemijskog sastava salive kod dijabetičara. Stomatološki glasnik Srbije. 2006; 53:209-16.

19. Mata AD, Marques D, Rocha S, Francisco H, Santos C, Mesquita MF, et al. Effects of diabetes mellitus on salivary secretion and its composition in the human. Mol Cell Biochem. 2004; 261:137-42.

20. Qureshi A, Qureshi A, Qureshi H, Khan AA. Blood glucose level, salivary $\mathrm{pH}$ and oral bacterial count in type 1 diabetic children. Infect Dis J. 2007; 16:45-8.

21. Jurysta C, Bulur N, Oguzhan B, Satman I, Yilmaz TM, Malaisse WJ, et al. Salivary glucose concentration and excretion in normal and diabetic subjects. I Biomed Biotechnol. 2009; 2009:430426.

22. Soares MSM, Batista-Filho MMV, Pimentel MJ, Passos IA, ChimenosKustner E. Determination of salivary glucose in healthy adults. Med Oral Patol Oral Cir Bucal. 2009; 14:e510-3.

23. Iqbal S, Kazmi F, Asad S, Mumtaz M, Khan A. Dental caries and diabetes mellitus. Pakistan Oral Dent J. 2011; 31:60-3.

24. Priyadarshini B, Uma R. Biomarkers in saliva of type I diabetes mellitus for diagnostic and prognostic significance. Am J Biopharm Biochem Life Sci. 2012; 1:A14.

25. Busato IMS, Ignácio SA, Brancher JA, Moysés ST, Azevedo-Alanis LR. Impact of clinical status and salivary conditions on xerostomia and oral health-related quality of life of adolescents with type 1 diabetes mellitus. Community Dent Oral Epidemiol. 2011; 40:62-9.

26. Gheena S, Chandrasekhar T, Pratibha Ramani. Salivary characteristics of diabetic children. Braz J Oral Sci. 2011; 10:93-7.

27. Aydin S. A comparison of gherlin, glucose, alpha-amylase and protein levels in saliva from diabetics.) Biochem Mol Biol. 2007; 40:29-35.

28. Vasconcelos AC, Soares MM, Almeida PC, Soares TC. Comparative study of theconcentration of salivary and blood glucose in type 2 diabetic patients. J Oral Sci. 2010; 52:293-8.

29. Abikshyeet P, Ramesh V, Oza N. Glucose estimation in the salivary secretion of diabetes mellitus patients. Diabetes Metab Syndr Obes. 2012; 5:149-54 
30. Lasisi T), Fasanmade AA. Comparative analysis of salivary glucose and electrolytes in diabetic individuals with periodontitis. Ann lbd Pg Med. 2012; 10:25-30.

31. Lopez ME, Colloca ME, Paez RG, Schallmach JN, Koss MA, Chervonagura A. Salivary characteristics of diabetic children. Braz Dent J. 2003; 14:26-31.

32. Carda C, Mosquera-Lloreda N, Salom L, Gomez de Ferraris ME, Peydró A. Structural and functional salivary disorders in type 2 diabetic patients. Med Oral Patol Oral Cir Bucal. 2006; 11:E309-E314.

33. Hegde A, Shenoy R, D'Mello P, Smitha A, Tintu A, Manjrekar P. Alternative markers of glycemic status in diabetes mellitus. Biomedical Research. 2010; 21:252-6.

34. Al-Rawi NH. Oxidative stress, antioxidant status and lipid profile in the saliva of type 2 diabetics. Diab Vasc Dis Res. 2011; 8:22-8.

35. Karjalainen S, Sewon L, Soderling E, Larsson B, Johansson I, Simell O, et al. Salivary cholesterol of healthy adults in relation to serum cholesterol concentration and oral health. J Dent Res. 1997; 76:1637-43.

36. West IC. Radicals and oxidative stress in diabetes. Diabet Med. 2000; 17:171-80.

37. Todorović T, Dožić I, Mandić B, Marjanović M. Antioksidativna uloga pljuvačke u očuvanju zdravlja usta. Vojnosanit Pregl. 2005; 62:575-9.

38. Todorović T, Dožić I. Uloga slobodnih radikala u patogenezi oralnih oboljenja. In: Đukić M, et al. Oksidativni stres - kliničko-dijagnostički značaj. Beograd: Mono i Manjana; 2008. p.177-190.

39. Bigagli E, Raimondi L, Mannucci E, Colombi C, Bardini G, Rotella CM, et al. Lipid and protein oxidation products, antioxidant status and vascular complications in poorly controlled type 2 diabetes. $\mathrm{Br}$ J Diabetes Vasc Dis. 2011; 12:33-9.

40. Arana C, Cutando A, Ferrera MJ, Gómez-Moreno G, Worf CV, Bolaños MJ, et al. Parameters of oxidative stress in saliva from diabetic and parenteral drug addict patients. J Oral Pathol Med. 2006; 35:554-9.

41. Streckfus CF, Marcus S, Welsh S, Brown RS, Cherry-Peppers G, Brown $\mathrm{RH}$. Parotid function and composition of parotid saliva among elderly edentulous African-American diabetics. J Oral Pathol Med. 1994; 23:277-9.

42. Yavuzyilmaz E, Yumak O, Akdoğanli T, Yamalik N, Ozer N, Ersoy F, et al. The alterations of whole saliva constituents in patients with diabetes mellitus. Aust Dent J. 1996; 41:193-7.
43. Kumar J. Saliva - a marker for the diabetic: a comparative study of healthy and the diabetic individuals. Indian J Innovations Dev. 2012; 1:92-6.

44. Al-Maroof RH. Alteration of saliva in insulin dependent diabetic patients and its relation to their periodontal status. Al-Rafidain Dent J. 2010; 10:102-9.

45. Sathyapriya S, Bharani GO, Nagalingam M, Jayanthi M, Kanagavalli U. Potential of salivary protein as a biomarker in prognosis of diabetes mellitus. Journal of Pharmacy Research. 2011; 4:2228-9.

46. Ben-Aryeh $H$, Serouya R, Kanter $Y$, Szargel R, Laufer D. Oral health and salivary composition in diabetic patients. J Diabetes Complications. 1993; 7:57-62.

47. Vaziri PB, Vahedi M, Abdollahzadeh SH, Abdolsamadi HR, Hajilooi $\mathrm{M}$, Kasraee $\mathrm{SH}$. Evaluation of salivary albumin in diabetic patients. Iranian Publ Health. 2009; 38:54-9.

48. Wong DT. Salivary diagnostics. American Scientist. 2008; 96:37-43.

49. Al Kawas S, Rahim ZHA, Ferguson DB. Potential uses of human salivary protein and peptide analysis in the diagnosis of disease. Arch Oral Biol. 2012; 57:1-9.

50. Rao PV, Reddy AP, Lu X, Dasari S, Krishnaprasad A, Biggs E, et al. Proteomic identification of salivary biomarkers of type-2 diabetes. J Proteome Res. 2009; 8:239-45.

51. Todorovic T, Vujanovic D, Dozic I, Petkovic-Curcin A. Calcium and magnesium content in hard tissues of rats under condition of subchronic lead intoxication. Mag Res. 2008; 21:43-50.

52. Aren G, Sepet E, Ozdemir D Dinççağ N, Güvener B, Firatli E. Periodontal health, salivary status, and metabolic control in children with type 1 diabetes mellitus. J Periodontol. 2003; 74:1789-95.

53. Moreira AR, Passos IA, Sampaio FC, Soares MS, Oliveira RJ. Flow rate, $\mathrm{pH}$ and calcium concentration of saliva of children and adolescents with type 1 diabetes mellitus. Braz J Med Biol Res. 2009; 42:707-11.

54. Jawed M, Khan RN, Shahid SM, Azhar A. Protective effects of salivary factors in dental caries in diabetic patients of Pakistan. Exp Diabetes Res. 2012; 2012:947304.

Received: 04/07/2012 • Accepted: 04/09/2012 


\title{
Biohemijski markeri u pljuvački osoba sa šećernom bolešću
}

\author{
Biljana Anđelski-Radičević1, Radica Dožić2, Tatjana Todorović1, Ivan Dožić1 \\ ${ }^{1}$ Opšta i oralna biohemija, Stomatološki fakultet, Univerzitet u Beogradu, Beograd, Srbija; \\ ${ }^{2}$ Fakultet medicinskih nauka, Univerzitet u Kragujevcu, Kragujevac, Srbija
}

\begin{abstract}
KRATAK SADRŽAJ
Diabet s mellitus (DM) ili šećerna bolest je metabolički sindrom koji se odlikuje poremećajem metabolizma ugljenih hidrata, lipida i proteina. Dijagnoza dijabetesa postavlja se određivanjem koncentracije glukoze u krvnom serumu standardizovanim metodama. Često merenje nivoa šećera u krvi izaziva nelagodnost kod bolesnika tokom postupka venepunkcije. Poslednjih godina sve više se analiziraju biološki materijali, kao što je pljuvačka, čiji je postupak prikupljanja neinvazivan. Na osnovu brojnih istraživanja dokazano je da dolazi do modifikacije organskih i neorganskih sastojaka pljuvačke (glukoza, lipidne i proteinske komponente, markeri oksidativnog stresa, elektroliti) kod osoba obolelih od DM. Pored ostalih markera, analiza glukoze u pljuvački je pokušaj da se pronađe neinvazivan i bezbolan način za često merenje glikemije kod ovih bolesnika. Prikupljanje pljuvačke jednostavno je za bolesnika, ne zahteva skupu opremu, niti posebno obučeno osoblje. Takođe, moguće je pljuvačku uzeti nekoliko puta i u neograničenim količinama. Na osnovu podataka o mogućnostima korišćenja pljuvačke kao biološkog uzorka u dijagnostikovanju DM, koji bi bio alternativa krvnom serumu, tj. plazmi, nameće se zaključak da ovaj sekret sve više dobija značaja u pomenutom kontekstu.

Ključne reči: dijabetes melitus; elektroliti; glukoza; markeri oksidativnog stresa; proteini; pljuvačka
\end{abstract}

\section{UVOD}

Diabetes mellitus (DM) ili šećerna bolest je metabolički sindrom koji karakteriše poremećaj metabolizma ugljenih hidrata, lipida i proteina. Odlikuje se hroničnom hiperglikemijom, kao rezultat poremećenog lučenja insulina ili povećane ćelijske rezistencije na delovanje insulina. Etiološka klasifikacija DM je: DM tip 1 (destrukcija beta-ćelija, potpuni nedostatak insulina), DM tip 2 (predominantna insulinska rezistencija s relativnim nedostatkom insulina do sekretornog deficita insulina s insulinskom rezistencijom), drugi specifični tipovi DM, gestacioni DM. Loša kontrola glikemije kod ovog oboljenja dovodi do narušavanja zdravlja bolesnika i pojave raznih komplikacija, kao što su retinopatija, nefropatija, neuropatija, kardiovaskularni simptomi itd. [1]. Osobe sa DM sklone su razvoju komplikacija u usnoj duplji, kao što su parodontalna oboljenja (gingivitis, parodontitis), karijes, salivarna disfunkcija, suvoća usta, oboljenja oralne mukoze i oralne infekcije (kandidijaza) [2-7].

Dijagnoza DM postavlja se određivanjem koncentracije glukoze u krvnom serumu standardizovanim metodama. Međutim, često merenje nivoa šećera u krvi izaziva nelagodnost kod bolesnika tokom postupka venepunkcije, zbog koje mnogi od njih nisu u mogućnosti da redovno beleže koncentraciju glukoze u krvi. Poslednjih godina čine se napori da se analize krvi zamene uzorcima biološkog materijala, čiji bi postupak prikupljanja bio neinvazivan. Jedan od takvih uzoraka svakako može biti i pljuvačka. Ona ima mnoge prednosti nad serumom, kao što je jeftin i neinvazivan postupak prikupljanja, uključujući jednostavnost skladištenja i isporuke [8-13].

\section{PLJUVAČKA KAO DIJAGNOSTIČKA TEČNOST}

Pljuvačka je telesna tečnost složenog sastava i specifičnih uloga. Analiza biohemijskih sastojaka pljuvačke je od velike pomoći kako pri dijagnostikovanju oboljenja usne duplje [14-17], tako i u utvrđivanju opšteg zdravstvenog stanja organizma [8]. Na osnovu brojnih istraživanja dokazano je da dolazi do modifikacije organskih i neorganskih sastojaka pljuvačke kod bolesnika sa DM $[18,19]$.

\section{GLUKOZA}

Tokom šećerne bolesti, kao posledica hiperglikemije, dolazi do stvaranja proizvoda metabolizma glukoze koji izazivaju mikrovaskularne promene u krvnim sudovima i na bazalnim membranama ćelija pljuvačnih žlezda i tkiva usne duplje [20]. Sve ove promene olakšavaju prelazak glukoze iz krvi u pljuvačku i gingivalnu tečnost. U literaturi ima različitih podataka o povezanosti koncentracije glukoze u krvi i koncentracije glukoze u pljuvački. Glukoza postoji u pljuvački zdravih osoba [21, 22], a mehanizam njenog lučenja još nije poznat. Predloženi su paraćelijski i međućelijski putevi lučenja glukoze, ali su to još hipoteze koje nisu potvrđene. Kod osoba sa DM tip 1 dokazana je povećana $[23,24,25]$ ili smanjena koncentracija glukoze $u$ pljuvački [26] u odnosu na kontrolnu grupu ispitanika. U pljuvački osoba sa DM tip 2 koncentracija glukoze je veća u odnosu na pljuvačku onih koji nisu oboleli od DM [27, 28, 29]. Lasisi (Lasisi) i Fasanmejd (Fasanmade) [30] dokazali su veću koncentraciju glukoze u pljuvački ispitanika sa DM u odnosu na one koji nisu oboleli od DM bez obzira na parodontalna oboljenja. Ovaj rezultat ukazuje na to da je koncentracija glukoze u pljuvački zavisna od njene koncentracije u serumu. Većina istraživanja, međutim, pokazuje da nema korelacije između glikemije i koncentracije glukoze u pljuvački obolelih od DM [28, $31,32,33]$. Autori smatraju da povećana koncentracija glukoze u pljuvački osoba sa DM može da podstakne razmnožavanje mikroorganizama i njihovu kolonizaciju na zubima i oralnoj mukozi. Analiza glukoze u pljuvački je pokušaj da se pronađe neinvazivan i bezbolan način za često merenje glikemije kod ovih bolesnika. 


\section{LIPIDNI STATUS}

Karakteristika bolesnika sa DM je i poremećaj metabolizma masti, koji nastaje kao posledica poremećaja metabolizma glukoze i promena u lučenju i delovanju insulina. Kao rezultat sistemske dislipidemije, kod ovih bolesnika dokazana je visoka koncentracija lipidnih frakcija u serumu, što se odražava i na njihovu koncentraciju u pljuvački. Dokazan je povećan nivo holesterola u pljuvački osoba obolelih od DM tip 1 [26], a kod obolelih od DM tip 2 koncentracija holesterola i triglicerida povećana je u serumu i pljuvački u odnosu na kontrolnu grupu ispitanika [34]. Koncentracija holesterola u pljuvački u korelaciji je s njegovom koncentracijom u serumu. Kod zdravih ljudi ova pozitivna korelacija može da se koristi pri odabiru osoba s visokim nivoom holesterola u serumu [35].

\section{MARKERI OKSIDATIVNOG STRESA}

Oksidativni stres ima važnu ulogu u patogenezi i komplikacijama DM. Kao posledica hiperglikemije dolazi do povećanog stvaranja kiseonikovih slobodnih radikala i poremećaja antioksidantnih odbrambenih mehanizama [36]. Kao najizraženiji negativni efekat delovanja slobodnih radikala navodi se oksidacija višestruko nezasićenih masnih kiselina u ćelijskim membranama, poznata kao lipidna peroksidacija, tokom koje se oštećuje plazma-membrana. Krajnji proizvod lipidne peroksidacije je kratkolančani malondialdehid (MDA), koji služi kao biohemijski pokazatelj stepena oksidativnog oštećenja ćelijskih membrana. Naša istraživanja pokazuju da se u pljuvački osoba obolelih od parodontalnih bolesti povećava sadržaj MDA u odnosu na zdrave ispitanike $[37,38]$. Ovaj marker povećan je u pljuvački bolesnika sa DM tip 2 [34,39], što ukazuje na to da povećanje MDA može biti marker visokog rizika od komplikacija kod bolesnika sa slabo kontrolisanim DM. Druga istraživanja su, međutim, dokazala nižu koncentraciju MDA u pljuvački osoba obolelih od DM u odnosu na kontrolnu grupu ispitanika [33]. Analiziranje ukupnog antioksidantnog kapaciteta pljuvačke kod osoba sa DM bilo je predmet nekoliko studija. Dokazan je povećan nivo glutation-peroksidaze, glutation-reduktaze, superoksid-dismutaze i mokraćne kiseline u pljuvački ovih bolesnika $[34,40]$. Povećanje koncentracije antioksidansa u pljuvački i serumu osoba obolelih od DM je odgovor na štetno delovanje slobodnih radikala tokom oksidativnog stresa. Na osnovu izloženih rezultata može se zaključiti da slobodni radikali i oksidativni stres mogu imati važnu ulogu u patogenezi DM. Dok god postoji ravnoteža između stvaranja slobodnih radikala i aktivnosti antioksidantnog sistema odbrane u pljuvački ne dolazi do oksidativnog oštećenja tkiva. Ukoliko dođe do disbalansa između stvaranja slobodnih radikala i/ili sposobnosti pljuvačnih antioksidansa da ih neutrališu, nastaje oksidativni stres, koji može biti biohemijska osnova za razvoj oboljenja usta i zuba bolesnika sa DM.

\section{PROTEINI}

U literaturi postoje različiti podaci o koncentraciji ukupnih proteina u pljuvački osoba obolelih od DM. Istraživanja pokazuju da je ukupna koncentracija proteina u pljuvački ovih bolesnika niža $[18,41,42,43]$, značajno povećana $[19,31,32,44,45]$ ili je bez promena u odnosu na kontrolnu grupu ispitanika $[25,27$, $30,46]$. U našim istraživanjima dokazana je niža koncentracija proteina u pljuvački bolesnika sa DM tip 1 u odnosu na one sa DM tip 2 [18], za razliku od drugih autora [19]. Najčešći protein krvi, albumin, dokazan je u nešto većoj koncentraciji u pljuvački dece sa DM u odnosu na zdravu decu, ali bez statističke značajnosti [26]. Drugi autori ukazali su na smanjenu koncentraciju albumina u pljuvački bolesnika sa DM tip 2 [32]. Dokazano je takođe da nema razlike u koncentraciji albumina $\mathrm{u}$ pljuvački ispitanika obolelih od DM tip 1 i kontrolne grupe, kao ni između ispitanika sa DM tip 1 i DM tip 2 [47]. Ovi podaci su saglasni s rezultatima naših istraživanja [18]. Različiti rezultati koncentracije proteina u pljuvački osoba sa DM mogu se objasniti činjenicom da su analize rađene u različitim stadijumima bolesti ili u različitim tipovima DM. Na koncentraciju ukupnih proteina u pljuvački verovatno uticaj imaju vrsta i način sakupljanja pljuvačke, način stimulacije, protok, metode određivanja, dnevne varijacije, brzina i trajanje centrifugiranja.

U poslednjih nekoliko godina, s tehnološkim razvojem, koriste se specifičnije i osetljivije metode u utvrđivanju ukupnih proteina ili peptida pljuvačke poznatih kao pljuvačni (salivarni) proteomi. Ovi proteomi su važni ne samo za razumevanje oralne patofiziologije, već mogu da budu korisni i kao potencijalni biomarkeri za sistemska oboljenja. Autori su dokazali da u pljuvački ima oko hiljadu proteina, s različitim ulogama u metaboličkim procesima, imunskoj regulaciji, ćelijskoj adheziji i komunikaciji itd. Oni su u pljuvački osoba sa DM tip 2 ustanovili proteome sa 487 proteina, među kojima je 65 proteina bilo značajno za diferencijaciju obolelih u odnosu na kontrolnu grupu ispitanika $[48,49,50]$. Većina ovih proteina uključena je u metaboličke procese i imunski odgovor organizma.

\section{ELEKTROLITI}

Promene koncentracije elektrolita u serumu mogu da se odraze na sistemska oboljenja, a u pljuvački mogu da utiču na promenu njene funkcije u remineralizaciji, održavanju puferskog kapaciteta, smanjenju funkcije čula ukusa itd. Pljuvačka je zasićena jonima kalcijuma, koji su u ravnoteži s jonima u hidroksiapatitu zubne gleđi. Pored toga, joni kalcijuma iz pljuvačke imaju ulogu posrednika u vezivanju različitih neorganskih i organskih supstanci za površinu zubne gleđi. Ovi joni takođe imaju ulogu u remineralizaciji gleđi $[8,51]$. Koncentracija kalcijuma u pljuvački varira u zavisnosti od koncentracije pljuvačnih proteina, protoka pljuvačke i lučenja pljuvačnih žlezda [52]. Kod bolesnika sa DM dokazano je povećanje koncentracije kalcijuma u pljuvački u odnosu na kontrolnu grupu ispitanika $[19,25$, 53]. Autori smatraju da je povišena koncentracija kalcijuma $u$ pljuvački ovih bolesnika povoljan indikator za oralno zdravlje. U literaturi, međutim, ima i drugačijih rezultata $[23,31,44,54]$. Pretpostavlja se da je snižena koncentracija kalcijuma u pljuvački bolesnika sa DM povezana sa smanjenjem protoka pljuvačke ili s povećanjem koncentracije proteina koji ostvaruju specifične veze s kalcijum-fosfatom. Mata (Mata) i saradnici [19] dokazali su smanjenu koncentraciju magnezijuma, cinka i kalijuma u pljuvački ovih bolesnika, što se dovodi u vezu sa disfunkcijom sekretornog kapaciteta pljuvačnih žlezda. U našim istraživanjima koncentracija kalijuma u pljuvački bolesnika sa DM veća je 
u poređenju sa zdravim ispitanicima [18]. To je u saglasnosti s rezultatima drugih autora, koji ukazuju na izmenjenu aktivnost Na-K-ATP-aze, usled promena u bazalnoj membrani acinusa pljuvačnih žlezda [44] ili smanjenja lučenja pljuvačke tokom dijabetesa [30]. Koncentracija kalijuma može da bude snižena [19, 42] ili bez promena u pljuvački osoba obolelih od DM [45]. Isti autori dobili su suprotne rezultate za koncentraciju natrijuma.

\section{ZAKLJUČAK}

Na osnovu prikazanih podataka o mogućnostima korišćenja pljuvačke kao biološkog uzorka u dijagnostikovanju DM, koji bi bio alternativa krvnom serumu, tj. plazmi, nameće se zaključak da ovaj sekret sve više dobija na značaju u pomenutom kontekstu. Prikupljanje pljuvačke je jednostavno i bezbolno za pacijenta, ne zahteva skupu opremu, ni posebno obučeno osoblje, što svakako govori u prilog ekonomičnosti rada. Takođe je moguće pljuvačku uzeti nekoliko puta i u neograničenim količinama. Nedostatak je, međutim, što pljuvačka kod obolelih od DM ne odražava realnu koncentraciju svih parametara u odnosu na krv. Tu je i problem izuzetno velike viskoznosti pljuvačke, zbog mukopolisaharida i mukoproteina, što može ometati analizu. Uprkos ovim ograničenjima, obimna istraživanja koja se sve češće rade sofisticiranim tehnikama pokazuju da pljuvačka predstavlja dijagnostičku tečnost budućnosti. 